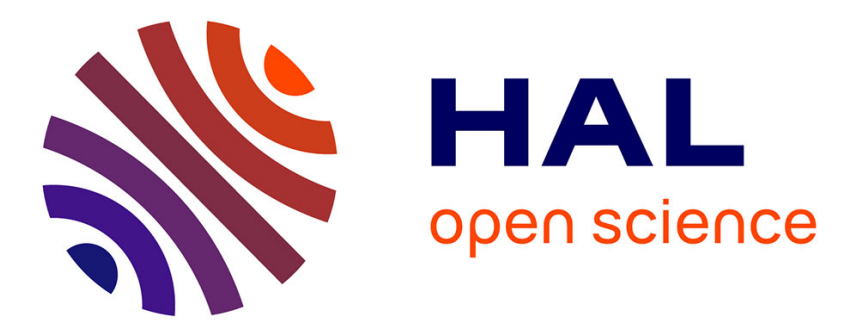

\title{
Analysis of artist's palette on a 16th century wood panel painting by portable and laboratory Raman instruments
}

Elisabetta Stanzani, Danilo Bersani, Pier Paolo Lottici, Philippe Colomban

\section{To cite this version:}

Elisabetta Stanzani, Danilo Bersani, Pier Paolo Lottici, Philippe Colomban. Analysis of artist's palette on a 16th century wood panel painting by portable and laboratory Raman instruments. Vibrational Spectroscopy, 2016, 85, pp.62-70. 10.1016/j.vibspec.2016.03.027 . hal-01303692

\section{HAL Id: hal-01303692 https: / hal.sorbonne-universite.fr/hal-01303692}

Submitted on 18 Apr 2016

HAL is a multi-disciplinary open access archive for the deposit and dissemination of scientific research documents, whether they are published or not. The documents may come from teaching and research institutions in France or abroad, or from public or private research centers.
L'archive ouverte pluridisciplinaire HAL, est destinée au dépôt et à la diffusion de documents scientifiques de niveau recherche, publiés ou non, émanant des établissements d'enseignement et de recherche français ou étrangers, des laboratoires publics ou privés. 


\title{
Analysis of artist's palette on a $16^{\text {th }}$ century wood panel painting by portable and laboratory Raman instruments
}

\author{
Elisabetta Stanzani ${ }^{\mathrm{a}, \mathrm{b}, \mathrm{c}}$, Danilo Bersani ${ }^{\mathrm{a}}$, Pier Paolo Lottici ${ }^{\mathrm{a}}$, Philippe Colomban ${ }^{\mathrm{b}, \mathrm{c}^{*}}$ \\ ${ }^{a}$ Università di Parma, Dipartimento di Fisica e Scienze della Terra, Parco Area delle Scienze 7/A, \\ 43124 Parma, Italia \\ ${ }^{\mathrm{b}}$ Sorbonne Universités, UPMC Univ Paris 06, UMR 8233, MONARIS, 75005, Paris, France \\ ${ }^{c}$ CNRS-IP2CT, UMR 8233, MONARIS, 75005, Paris, France
}

* Corresponding author e-mail philippe.colomban@upmc.fr

Fax: +33144273021 Tel: +33144272785

\section{Highlights}

Comparative evaluation of fixed and (trans)portable Raman instruments for the characterization of pigments used in $16^{\text {th }}$ century wood panel painting.

The pigments (white lead, calcite, cerussite, litharge, vermilion, minium, azurite, lapis lazuli, indigo) and other ingredients (gypsum, egg and terpenic resins) detected during the study of are in accordance with the stylistic dating.

Respectively 3,10, 12 and 8 pigments are identified with 532, 633, 785 and $1064 \mathrm{~nm}$ exciting lines using laboratory instrumentation (spectrometers excited with 532, 633 and $785 \mathrm{~nm}$ lines are transportable).

\begin{abstract}
Non-destructive analysis of the artist's palette of ancient wooden panel paintings is a difficult task and studies are rare. Here we compare different methods of analysis of a wooden panel painting, dated to the early sixteenth century, mainly by Raman and infrared spectroscopies. Raman spectra were recorded on collected/sampled micrometric fragments using portable Raman instruments with laser excitation lines at 532 and $785 \mathrm{~nm}$ and transportable Raman instruments at 532, 633 and 785 $\mathrm{nm}$; a fixed $1064 \mathrm{~nm}$ Raman spectrometer was also used. Infrared analyses were performed in Attenuated Total Reflection (ATR- FTIR) mode. Using the portable instrument, the Raman spectra evidenced white lead, calcite and vermilion only. Raman spectra recorded by transportable and fixed instruments enabled the identification of most of the artist's palette: i) white lead, calcite,
\end{abstract}


gypsum and cerussite for white colour; ii) vermilion, red lead, litharge, haematite for red; iii) azurite, indigo and lapis lazuli for blue. IR spectra gave information on the organic binding media. $\mathrm{XRF}$ analysis on a brown pigment suggested an heterogeneous mixture of a red pigment (such as haematite and/or minium) and a green one as malachite. GC-MS analysis allowed identifying terpenic resin in the composition of the outer protective layer.

Keywords: Wood panel painting; 16th century; Pigments; Binders; Raman spectroscopy; FTIR 


\section{Introduction}

Pigments and binders identification in paintings is very important to document the history, provenance, dating and artist's palette. Preferred analytical techniques are those preserving the integrity of the sampled material, or much better the in situ, non-invasive techniques, and recording spectra of small volumes (not more than 1-5 $\mu \mathrm{m}^{3}$ ) of organic and inorganic materials. In recent years, the use of Raman and infrared vibrational spectroscopies for the non-destructive characterization of art objects [1-7] has become dominant, especially with the rapid development of portable spectrometers for on-site measurements [8-12]. The varnish covering, however, makes the direct recording of the pigments signature and stratigraphy difficult for most of the paintings.

On site Raman micro-spectroscopy has proved its efficiency for more than 10 years in the study of different artworks $[13,14]$. Analysis of ancient wood panel paintings is however very limited: to our knowledge, only two medieval painted artefacts, a $14^{\text {th }}$ century wood panel painting and a sculpture, have been comprehensively studied $[15,16]$, but not using vibrational spectroscopy. Samples from $16^{\text {th }}$ century Perugino paintings [17] and $15^{\text {th }}$ century ceiling panels [18] have been analysed using FT-IR in combination with elemental analysis (SEM-EDX). Very recently similar works has been made for $14^{\text {th }}$ and $16^{\text {th }}$ century panels, namely using alternative techniques (XRF, NMR, XPS) [19-21]. Comprehensive analysis with vibrational spectroscopies was only conducted on $17^{\text {th }}$ century paintings [22] and more recent paintings have been studied by wide spectral range hyperspectral imaging [23]. Fluorescence generally overcomes the Raman signal recorded on ancient paintings, because of the use of solvents and glues. Collecting spectra requires the analysis of many samples, their preparation in order to find fluorescence-free spots and the testing of different excitation laser lines. Studies on icons $[24,25]$ are more numerous, the different painting technique making the measuring conditions more convenient.

We will consider here a painting on a flat wood panel. The artwork probably was an altarpiece (Fig. S1, Supplementary Materials): the only information available is the stylistic dating by Blanc Monique, a Middle Ages specialist, who placed it at the beginning of 16th century, just when canvas paintings began to become more popular than wood panels paintings. The artwork was originally composed of three parts - now incomplete - and probably represented the Lamentation on the Dead Christ: the Christ's body lies in the arms of the Virgin Mary and is accompanied by two unidentified figures. In the upper left part of the board an angel is visible, while on the right only the wings of another figure can be seen.

Our objective was to evaluate the use of Raman spectroscopy using portable, transportable and fixed instruments for the non-destructive identification of the ingredients employed in the 
realization of a wooden panel painting in order to collect information about the artist's palette. Due to the very limited number of Raman studies on ancient wood panel paintings, we try here to establish the methodology on a wood panel belonging to a private collection, the owner giving the permission to recover small scales fallen down and to collect a few samples. The experience gained should permit further studies on artefacts with known pedigree, especially to document the stratigraphy. The infrared absorption spectroscopy (FT-IR) was used as a complementary technique to detect and classify the organic substances. Additional analyses like X-ray fluorescence (XRF) and gas-chromatography coupled with mass spectroscopy (GC-MS) have been carried out to get more information about the protective layer, to determine if some kind of resin is present.

\section{Experimental}

The painting consists of two wooden panels, but only the right one was selected for analysis (1.55 m x $0.26 \mathrm{~m}$, thickness $\sim 2.5 \mathrm{~cm}$, Fig. S1, Supplementary Materials).

\subsection{Mobile Raman spectroscopy}

Investigation with mobile Raman instruments was made using HE785 and HE532 instruments (Horiba Scientific Jobin-Yvon, Longjumeaux, France), equipped with a matrix chargecoupled device (CCD) detector cooled by Peltier effect at $200 \mathrm{~K}$. A $785 \mathrm{~nm} 300 \mathrm{~mW}$ OEM laser (Process Instruments Inc., Salt Lake City, USA) and a $532 \mathrm{~nm} 100 \mathrm{~mW}$ Ventus (Laser Quantum, Cheshire, UK) were coupled to the above designed spectrometer, as well as with 785 and $532 \mathrm{~nm}$ remote SuperHead ${ }^{\circledR}$ optical heads equipped with selected high quality edge filters. The $785 \mathrm{~nm}$ Superhead ${ }^{\circledR}$ is equipped with a camera to select the exact point for the measurement. A 100x Nikon and a 100x IR optimized Olympus long working distance objectives were used. This equipment has very high sensitivity but medium resolution $\left(\sim 4 \mathrm{~cm}^{-1}\right)$; it can be easily transported as the components are independent and connected by cables or removable optical fibers. A black textile was used to protect the operators' eyes and to decrease the background level. The equipment was installed on a worktable in order to have the SuperHead ${ }^{\circledR}$ turned down and to be able to adjust manually the distance of the artwork with a XYZ micrometre stage. Note that the spectral window measured with portable instrument ranges from 80 to $3200 \mathrm{~cm}^{-1}$. Furthermore, because the decrease of the CCD sensitivity above $2000 \mathrm{~cm}^{-1}$ for the $785 \mathrm{~nm}$ excitation, corresponding band intensities are strongly decreased.

The remote SuperHead ${ }^{\circledR}$ was positioned using a horizontal or vertical XYZ stage with controlled micrometric displacement. Due to the strong fluorescence, no good Raman spectrum was obtained. Consequently, millimetre-sized samples that had fallen from the artefact or 
gently taken via scalpel were put in a groove, carved in a metal support (no preparation is made), in order to examine the section from the top without any preparation. Samples of various colours were taken from different parts of the painting: the blue of the sky, the dark and light blue of the Virgin veil, the white and the red of the skin of Christ and the brown of the Christ robe. At least 4 different samples for each colour have been studied. Each of them has been measured on different spots with different instruments (about one hundred Raman spectra). The most representative are presented.

\subsection{Optical microscopy}

The samples were observed with a BX51 (OLYMPUS, Japan) optical microscope equipped with $5 \mathrm{x}, 10 \mathrm{x}, 20 \mathrm{x}, 50 \mathrm{x}$ and 100x objectives, without any preparation, in order to have conditions similar to on-site analysis. As above mentioned, the sample was positioned in the groove to have the section horizontal (Fig.1).

\subsection{Laboratory Raman spectroscopy}

Three confocal Raman spectrometers with exciting wavelength varying from 532 to 1064 $\mathrm{nm}$ working in backscattering configuration were exploited:

i) A Senterra (Bruker Optics, Karlsruhe, Germany) micro-spectrometer equipped with a Peltier-cooled CCD matrix and two laser sources (YAG $532 \mathrm{~nm}$ and diode $785 \mathrm{~nm}$ ). A 100x long working distance OLYMPUS objective was selected (spot diameter $\sim 5 \mu \mathrm{m}$ ). The power range on the sample's surface was between 10 and $25 \mathrm{~mW}$, for typical $3 \times 80 \mathrm{~s}$ acquisitions. Note the design of this instrument makes its transportation out of the laboratory fast and easy.

ii) A confocal Raman microspectrometer LabRam Infinity (Dilor, Lille, France), equipped with a Peltier-cooled CCD matrix and a microscope with horizontal and vertical exits, and with two laser sources: YAG and $\mathrm{He}-\mathrm{Ne}$ (532 and $633 \mathrm{~nm}$, respectively). A 100x long working distance OLYMPUS objective was selected. The laser power on the sample surface was kept between 0.1 and $5 \mathrm{~mW}$. This instrument is transportable.

iii) A Fourier transform (FT) Raman RFS100/S micro-spectrometer from Bruker Optics (Ettlingen, Germany), with a 1064 nm YAG laser excitation and 100x and 40x OLYMPUS objectives optimised for IR wavelengths. It was equipped with a Michelson interferometer and a liquid nitrogen germanium detector. Typical parameters of analysis were $55 \mathrm{~mW}$ as power on the sample's surface, and 3,000 to 10,000 scans.

With the Senterra spectrometer operating at $785 \mathrm{~nm}$, the analysis was made at low excitation power on the sample in order to avoid/limit photo-oxidation phenomena. 
Absence of degradation was controlled by microscope examination. When needed, the Raman spectra are baseline subtracted with LabSpec 5 software (Horiba Scientific Jobin-Yvon).

\subsection{Infrared spectroscopy}

The IR spectra were recorded with an ATR Equinox 55 set-up associated with a FTIR Irscope II microscope with Cassegrain objectives able to work in transmission or reflection. Both instruments are from Bruker Optics. Spot diameter ranges from 30 to $4000 \mu \mathrm{m}$. A second series of analyses was carried out with a spectrophotometer NICOLET MOD. 5700, provided with software implemented by THERMO ELECTRON SPA, coupled with ATR accessory and diamond crystal.

The ATR-FTIR technique was applied both on raw and powdered fragments but the pressure of the analyser's crystal caused the crumbling of the raw samples. It was possible therefore to obtain information on different levels: the first spectra acquired may be referred to the surface, while the subsequent ones to the wood and preparatory layers. The most representative spectra will be discussed.

\subsection{Additional analyses}

Additional analyses by XRF and GC-MS were carried out in order to investigate the composition of the brown colour and to obtain more information about the protective layer as exemplified in previous works [26,27]. XRF measurements were made using a BRUKER ARTAX 200 spectrometer (Bruker AXS, Karlsruhe, Germany) equipped with molybdenum source, at an electric accelerating potential of $50 \mathrm{kV}$ and a current of $700 \mu \mathrm{A}$.

GC-MS analyses were performed on a solid-phase micro-extraction coupling with gas chromatography and mass spectrometry (SPME-GC-MS) using a Stableflex fiber and $85 \mu \mathrm{m}$ Carboxen/PDMS coating. For each analysis, the blank spectrum was recorded in identical conditions and the identified compounds were subtracted. In this way only the additional peaks were analysed. Peaks positions and relative intensities were compared to the mass spectra recorded on standards. Note that chromatograms are required in total ion current (TIC) mode. For the gas chromatographic separation, a fused silica capillary column Restek Rxi 1ms (55 m x $250 \mu \mathrm{m}, 1 \mu \mathrm{m}$ film thickness) and He as carrier gas were used; the injector was in splitless condition mode at 270 ${ }^{\circ} \mathrm{C}$. The extraction time was $80 \mathrm{~min}$ at $50^{\circ} \mathrm{C}$. The MS transfer line temperature was $280{ }^{\circ} \mathrm{C}$.

\section{Results and discussion}

\subsection{Stratigraphy}


The studied fragments were of approximate area up to $0.8 \times 0.9 \mathrm{~mm}^{2}$. The samples were observed with an optical microscope both on the surface and on the stratigraphic section in order to locate the points of interest for further analysis. As shown in Fig. 1, the sample stratigraphy evidences different layers: the wooden board, (many) preparatory coatings, the pictorial layer and a final darker layer, due to a protective layer and/or degradation of the painting. The preparatory films were about 200-300 $\mu \mathrm{m}$ thick, the painting layer about $400 \mu \mathrm{m}$ (red samples were thinner) and the upper one approximately $10-20 \mu \mathrm{m}$.

\subsection{Raman analyses with mobile instruments}

Raman spectra recorded with HE532 portable spectrometers on the painting top surface and on the sample section exhibit a huge fluorescence. Thus, the identification of pigments and binders was impossible. Conversely, the analyses carried out with portable HE785 set-up directly focussing the laser on the painting layer or on the small fragments sampled, allowed identifying some of the pigments employed by the artist.

Regarding the blue sample taken from the Virgin veil, a typical spectrum with portable Raman HE785 was completely masked by huge fluorescence (Fig. 2a). In the Christ body the white pigment was identified as a mixture of basic lead (II) carbonate, $2 \mathrm{PbCO}_{3} \cdot \mathrm{Pb}(\mathrm{OH})_{2}[13,14,28]$, known as "white lead", with its intense peak at $1054 \mathrm{~cm}^{-1}$, and of calcium carbonate, or calcite, with the most intense peak at $1085 \mathrm{~cm}^{-1}$ [28, 29] (Fig. 2b). Another pigment detected by portable Raman instrument in the Christ body flesh tone was identified as $\alpha$-mercury (II) sulphide, or vermilion, with typical peaks at 251,285 and $341 \mathrm{~cm}^{-1}[13,14,30]$ (Fig. 2c).

\subsection{Characterization by fixed laboratory Raman and infrared instruments}

\subsubsection{Raman analysis}

Figs. 3-5 report representative Raman spectra obtained with the laboratory Raman instruments at $532 \mathrm{~nm}, 633 \mathrm{~nm}, 785 \mathrm{~nm}$ and $1064 \mathrm{~nm}$.

For the white colour of the Christ flesh tone, the most widespread pigment detected was hydrocerussite, through its characteristic peaks at about 1040 and $1054 \mathrm{~cm}^{-1}$ [13,14,31,32]. For instance, in Fig. 4a taken with $633 \mathrm{~nm}$ line, a zoom on the spectrum shows a double peak characteristic of hydrocerussite. However, because of the limited resolution and/or local dehydration under the laser beam, the observation of a single peak doesn't exclude the presence of hydrocerussite. Calcite was also observed, characterized by the peaks at $283,713 \mathrm{~cm}^{-1}$ and the most intense one at $1085 \mathrm{~cm}^{-1}$ (Fig. 3b). Both compounds were visible with all laser sources used, excluding the $532 \mathrm{~nm}$ one. In the Raman spectrum of a sample, taken with the $785 \mathrm{~nm}$ excitation, 
the features of vermilion are also evidenced (Fig. 3c). In addition, weak Raman signals at 1051, 1307, 1442 and $1600 \mathrm{~cm}^{-1}$, attributed to a proteic binding medium [33-36], were found by FTRaman in the white sample coming from the Christ flesh tone (Fig. 3d).

The Raman spectra recorded on a red sample from the Christ flesh tone are shown in Fig. 4. The spectra taken with the laser sources at 532 and $785 \mathrm{~nm}$ have shown the presence of tetragonal lead (II) oxide (litharge) with peaks at 85, 140, 279 and $373 \mathrm{~cm}^{-1}$ [13,14,32] (Fig. 4a). Vermilion was identified as the main pigment chosen for the realization of flesh tone: its very intense spectrum, with peaks at 254, 284 and $343 \mathrm{~cm}^{-1}$ [30] (Fig. 4b-c), was usually found in this sample with all laser lines except at $532 \mathrm{~nm}$. The higher difficulty to observe vermilion with the $532 \mathrm{~nm}$ laser line should be attributed not only to the higher fluorescence but also to the lack of resonance effects [34]. Minium was detected by all the dispersive Raman systems (at 532, 633 and $785 \mathrm{~nm}$ ), identified by its characteristic peaks at 124, 154, 227, 316, 392 and $550 \mathrm{~cm}^{-1}$ [32] (Fig. 4d); note that this compound was rarely found mixed with vermilion.

Fig. 5 reports the Raman spectra obtained on the Virgin veil and on the sky. In the sample taken from the light blue sky, the main pigment is azurite, a basic copper (II) carbonate, detected with all the instruments, except when using the $633 \mathrm{~nm}$ line. In Fig. 5a are shown the weak peaks of azurite at 248 and $400 \mathrm{~cm}^{-1}$ detected by the $532 \mathrm{~nm}$ laser source [13,14,37]. In the sky, azurite is usually found together with white lead. Indigo, an organic dye extracted from the Indigofera tinctoria, was also detected as secondary blue pigment in the sky fragment. In the dark blue of the Virgin veil, indigo was clearly identified as the main pigment by its Raman peaks at 253, 390, 277, $546,599,756,1226,1310,1572$, and $1584 \mathrm{~cm}^{-1}[38,39]$ when exciting at 633,785 and $1064 \mathrm{~nm}$ (Fig. 5b-d; see an example of a baseline-subtracted spectrum in b'; baseline subtraction highlights the small bands detected on the raw spectrum). On the same sample, the $1064 \mathrm{~nm}$ excitation gave the Raman spectrum of indigo, with some features of azurite (Fig. 5d). With the $785 \mathrm{~nm}$ wavelength, the feature at $546 \mathrm{~cm}^{-1}$ reveals the presence of lapis lazuli [40-42] (Fig. 5b). The latter pigment was most likely mixed in little quantities with indigo to deepen the blue mantle of the Virgin Mary. Thanks to the red laser source at $633 \mathrm{~nm}$, in a light blue sample from the sky it was also possible to identify calcium sulphate di-hydrate (gypsum), by its strongest peak at $1008 \mathrm{~cm}^{-1}$ (Fig. 5c) [13].

In the brown sample coming from the Christ cloth, only the red/orange pigments were detected. In particular, diffuse minium signals were found at 633 and $785 \mathrm{~nm}$. Minor vermilion was also detected, using all the laser lines except the $532 \mathrm{~nm}$ one.

Table 1 summarizes the pigments identified by Raman microspectroscopy and compares the efficiency of portable, transportable and fixed instruments excited with different lasers: the portable 
laser source $532 \mathrm{~nm}$ ( 3 compounds identified) gave Raman spectra mostly affected by fluorescence, which prevented identification of most pigments. The portable Raman spectrometer with laser source $785 \mathrm{~nm}$ identified only 3 pigments: the use of a 40IRx objective promotes the detection of the scattered light. The pigments identified were vermilion, white lead and calcite, while no blue pigments has been detected. On the other hand, using a $785 \mathrm{~nm}$ (transportable) instrument, 12 ingredients were identified to be compared to the 10 and 8 compounds identified with 633 (transportable) and $1064 \mathrm{~nm}$ (fixed) ones.

\subsubsection{Infrared analysis}

In Fig. 6 are reported representative ATR-FTIR spectra obtained.

White lead was identified in all samples by the ATR-FTIR technique by the bands at 681 , 1380-1440, 1710-1730 and $3534 \mathrm{~cm}^{-1}$ [43]. In addition the infrared signatures of calcite were observed at 714, 870, 1410 in all samples (Fig. 6 b,c,d).

The ATR-FTIR spectrum of the blue sample (Fig. 6a, b) shows a contribution at 1032 and at $1094 \mathrm{~cm}^{-1}$ (Si-O stretching), which can be compatible either with traces of lapis lazuli or with glass/smalt [41, 42]; azurite was also identified through its IR characteristic absorption band at 1404 $\mathrm{cm}^{-1}[43,44]$. Indigo was difficult to detect due to its mixture with white lead, which shows high IR absorption, but in some spectra his characteristic peak at $1076 \mathrm{~cm}^{-1}$ was observed [38].

For the brown coloured sample, ATR-FTIR gave the spectra of calcite, gypsum, with his characteristic signatures at 600,670, 1110, 1795, 3403, 3531 cm-1 [45] (Fig. 6d), and white lead, likely used as preparatory bases for the painting layer. Minium was also detected by the infrared sharp peak at $1514 \mathrm{~cm}^{-1}$ [43] (Fig. 6b-c).

Concerning the red fragments taken from the Christ flesh tone, identification of vermilion by infrared spectroscopy was not possible due to the absence of signal from the Hg-S bond [43].

ATR-FTIR features from the wood layer were detected (Table 2). [46, 47] In all samples the signatures due to the binder were identified: in particular the peaks at 2920, 2850 (C-H stretching) and $1730 \mathrm{~cm}^{-1}$ (ester $\mathrm{C}=\mathrm{O}$ stretching band) were ascribable to triglycerides, while those at 1650 and $1540 \mathrm{~cm}^{-1}(\mathrm{C}=\mathrm{O}$ stretching and $\mathrm{N}-\mathrm{H}$ bending vibrations) are characteristic of amide I and amide II of proteins, respectively [34-36,44,48]. The detected peaks are compatible with the egg tempera technique (Fig.6a). The $\mathrm{C}=\mathrm{O}$ vibration of free fatty acids and the characteristic $\mathrm{O}-\mathrm{C}-\mathrm{O}$ stretching band of calcium oxalates were identified at $\approx 1710$ and $1320 \mathrm{~cm}^{-1}$, respectively: both are known to be the result of organic binders' degradations phenomena [33-36, 48,49]. A strong peak at 1696$1698 \mathrm{~cm}^{-1}$ and other bands at 1453 and $1379 \mathrm{~cm}^{-1}$, ascribable to the deformation of $\mathrm{CH}_{2}$ groups, 
suggest a terpenic resin [50]. The comparison with a spectrum of fresh fir tree resin confirms this hypothesis (Fig. S2, Supplementary Materials). Overall, 7 pigments were identified.

\subsection{Additional information obtained by XRF and GC-MS analysis}

Trying to complete the characterization of the brown sample collected from the Christ's cloth, the fragments were investigated with X-ray fluorescence spectroscopy (XRF). Under an optical microscope, some brown fragments indicate the presence of a green pigment coupled with a red one. The XRF data showed a high content of metals, including $\mathrm{Pb}, \mathrm{Cu}, \mathrm{Fe}$ and $\mathrm{K}$ (Fig. 7). The presence of lead is consistent with the presence of minium, already detected by Raman spectroscopy. Copper could be related to pigments used as blue or green components to obtain the brown colour.

The characterization of the painting's final layer was made by GC-MS. The samples were analysed with the aim of identifying volatile products. The first sample showed $\alpha$-pinene, a second terpene, canphene and its ester, CAS 000475-20-7 longifolene, borneol, CAS 003310-02-9 sabinol and CAS 001196-01-6 laevo-verbenone; while the second sample presented $\alpha$-pinene, copaene, azulene derivatives and Trans-pinocarveol (Table S1, Fig. S3, Supplementary Materials). These are all compounds of natural origin, which can be found particularly in essential oils as expected in ancient varnish.

\section{Conclusion}

The pigments (white lead, calcite, cerussite, litharge, vermilion, minium, azurite, lapis lazuli (+smalt?), indigo) and other compounds (gypsum, egg and terpenic resins) detected during the study are in accordance with the stylistic dating (beginning of the $16^{\text {th }}$ century).

This study enabled to evaluate and compare fixed, transportable and portable instruments in the characterization of pigments and binders used for the preparation of a wood painting. In most of the cases, for the instrument with laser source at $532 \mathrm{~nm}$, fluorescence prevented obtaining Raman spectra, while the laser source at $785 \mathrm{~nm}$, equipped with a camera helping the selection of the analysed spots, allowed identifying only part of the pigments. As expected, more sophisticated Raman spectrometers, and especially those with 633 and $785 \mathrm{~nm}$ excitation, were effective to determine a high number of compounds (12 and 10, respectively) employed for the artwork investigated, either organic or mineral, in the preparatory and painting layers.

Confocality of the sophisticated instruments and the use of high quality, high magnification microscope objectives $(100 \mathrm{x}$ or $200 \mathrm{x})$, optimised for the collected wavelength range, are very helpful to limit fluorescence arising from the material surrounding the pigments, increasing the 
signal to noise ratio. In addition, only the micro-Raman configuration, thanks to its very high lateral resolution, allows the complete characterization of the different layers of the pictorial stratigraphic sections. The great potential of mobile Raman equipment, very useful in many fields of conservation sciences (i.e. characterization of mounted gems, study of wall paintings) is limited when dealing with paintings containing a large amount of fluorescent materials like glues and varnishes.

Use of a variety of exciting wavelengths is mandatory to identify the different colouring agents. Consequently, conclusions obtained from single laser line measurements are limited. Note that most of previous studies regarding paintings used one or two laser lines, which explains the very limited number and content of previous Raman studies.

By the ATR-FTIR technique the bands concerning the wooden support were easily detected and the media used for the painting were identified. The preparatory layers were made of calcite/gypsum and the glue and the pigments were applied according the egg tempera technique. In addition, some preliminary information about the use of a terpenic resin as protective layer for the painting has been obtained by GC-MS analyses.

\section{Acknowledgements}

Mrs Monique Blanc, Chief Curator at the Middle Ages Department, Musée des arts décoratifs, Paris is kindly acknowledged for the dating of the wood panel painting. The authors would like to thank Drs Pietro Baraldi and Paolo Zannini from the University of Modena for the additional XRF and CG-MS analyses. 


\section{References}

[1] G.D. Smith, R.J.H. Clark, J. Archaeol. Sci. 31 (2004) 1137-1160.

[2] P. Ricciardi, Ph. Colomban, A. Tournié, M. Macchiarola, N. Ayed, J. Archaeol. Sci. 36 (2009) $2551-2559$.

[3] L. He, N. Wang, X. Zhao, T. Zhou, Y. Xia, J. Liang, B. Rang, J. Archaeol. Sci. 39 (2012) 18091820.

[4] Ph. Colomban, D. Mancini, Arts. 2 (2013) 111-123.

[5] F. Rosi, A. Daveri, C. Miliani, G. Verri, P. Benedetti, F. Piqué, B.G. Brunetti, A. Sgamellotti, Anal. Bioanal. Chem. 395 (2009) 2097-2106.

[6] P. Vandenabeele, F. Verpoort, L. Moens, Small. (2001) 263-269.

[7] S. Bruni, S. Cariati, F. Casadio, I. Toniolo, Spectrochim. Acta Part A - Mol. Biomol. Spectrosc. 55 (1999) 1371-1377.

[8] D. Lauwers, A.G. Hutado, V. Tanevska, L. Moens, D. Bersani, P. Vandenabeele, Spectrochim. Acta - Part A Mol. Biomol. Spectrosc. 118 (2014) 294-301.

[9] P. Vandenabeele, K. Castro, M. Hargreaves, L. Moens, J.M. Madariaga, H.G.M. Edwards, Anal. Chim. Acta. 588 (2007) 108-116.

[10] Ph. Colomban, J. Cult. Herit. 9 (2008) 55-60.

[11] A. Deneckere, F.P. Hocquet, A. Born, P. Klein, S. Rakkaa, S. Lycke, K. De Langhe, M.P.J. Martens, D. Strivay, P. Vandenabeele, L. Moens, J. Raman Spectrosc. 41 (2010) 1500-1509.

[12] C. Miliani, F. Rosi, B.G. Brunetti, A. Sgamellotti, Accounts Chem. Res. 43 (2010) 728-738.

[13] I.M. Bell, R.J.H. Clark, P.J. Gibbs, Spectrochim. Acta Part A-Mol. \& Biomol. Spectrosc. 53 (1997) 1491-1521.

[14] L. Burgio, R.J.H. Clark, Spectrochim. Acta Part A-Mol. \& Biomol. Spectrosc. 57 (2001) 21592179.

[15] A. Atrei, F. Benetti, S. Bracci, D. Magrini, N. Marchettini, J. Cult. Herit. 15 (2014) 80-84.

[16] M.L. Franquelo, M.D. Robador, J.L. Pérez-Rodríguez, Eur. J. Sci. Theol. 11 (2015) 149-158.

[17] C. Ricci, I. Borgia, B.G. Brunetti, C. Miliani, A. Sgamellotti, C. Seccaroni, P. Passalacqua, J. Raman Spectrosc. 35 (2004) 616-621.

[18] M. Malagodi, T. Rovetta, M. Licchelli, Heritage Sci. 2 (2014) 1-9.

[19] C. Pellerito, A. E. Di Marco, M.C. Di Natale, B. Pignataro, M. Scopelliti, M. Sebastianelli, Microchem. J. 124 (2016) 682-692.

[20] C. Ruberto, A. Mazzinghi, M. Massi, L. Castelli, C. Czelusniak, L. Palla, N. Gelli, M. Betuzzi, A. Impallaria, R. Brancaccio, E. Peccenini, M. Raffaelli, Microchem. J. 126 (2016) 63-69. 
[21] V. Di Tullio, D. Capitani, A. Atrei, F. Benetti, G. Perra, F. Presciutti, N. Proietti, N. Marchettini, Microchem. J. 125 (2016) 208-218.

[22] E. Pięta, E. Proniewicz, B. Szmelter-Fausek, J. Olszewska-Świetlik, L.M. Proniewicz, Spectrochim. Acta Part A Mol. Biomol. Spectrosc. 136 (2015) 594-600.

[23] S. Legrand, F. Vanmeert, G. Van der Snickt, M. Alfed, W. De Nof, J. Dik, K. Janssens, Heritage Sci. 2 (2014) 1-13.

[24] S. Daniilia, D. Bikiaris, L. Burgio, P. Gavala, R.J.H. Clark, Y. Chryssoulakis, J. Raman Spectrosc. 33 (2002) 807-814.

[25] L. Burgio, R.J.H. Clark, K. Theodoraki, Spectrochim. Acta Part A Mol. Biomol. Spectrosc. 59 (2003) 2371-2389.

[26] M.P. Colombini, F. Modugno, S. Giannarelli, R. Fuoco, M. Matteini, Microchem. J. 67 (2000) 385-396.

[27] G. Leo, L. Cartechini, P. Pucci, A. Sgamellotti, G. Marino, L. Birolo, Anal. Bioanal. Chem. 395 (2009) 2269-2280.

[28] M. H. Brooker, S. Sunder, P. Taylor, V. J. Lopata, Canad. J. Chem. 61 (1983) 494-502.

[29] M. Pérez-Alonso, K. Castro, I. Martinez-Arkarazo, M. Angulo, M.A. Olazabal, J.M. Madariaga, Anal. Bioanal. Chem. 379 (2004) 42-50.

[30] S. V Gotoshia, L. V Gotoshia, J. Phys. D. Appl. Phys. 41 (2008) 115406.

[31] D. Bersani, P.P. Lottici, A. Casoli, D. Cauzzi, J. Cult. Herit. 9 (2008) 97-102.

[32] L. Burgio, R.J. Clark, S. Firth, Analyst 126 (2001) 222-227.

[33] E. Joseph, S. Prati, G. Sciutto, M. Ioele, P. Santopadre, R. Mazzeo, Anal. Bioanal. Chem. 396 (2010) 899-910.

[34] P. Vandenabeele, B. Wehling, L. Moens, H. Edwards, M. De Reu, G. Van Hooydonk, Anal. Chim. Acta. 407 (2000) 261-274.

[35] S. Ngarize, A. Adams, N.K. Howell, Food Hydrocoll. 18 (2004) 49-59.

[36] G. Burrafato, M. Calabrese, A. Cosentino, A.M. Gueli, S.O. Troja, A. Zuccarello, J. Raman Spectrosc. 35 (2004) 879-886.

[37] R.L. Frost, W.N. Martens, L. Rintoul, E. Mahmutagic, J.T. Kloprogge, J. Raman Spectrosc. 33 (2002) 252-259.

[38] P. Vandenabeele, L. Moens, Analyst 128 (2003) 187-193.

[39] A. Domenech, T. Domenech-Carbo, H.G.M. Edwards, J. Raman Spectrosc. 42 (2011) 86-96.

[40] Ph. Colomban, J. Raman Spectrosc. 34 (2003) 420-423.

[41] M. Favaro, A. Guastoni, F. Marini, S. Bianchin, A. Gambirasi, Anal. Bioanal. Chem. 402 (2012) 2195-2208. 
[42] M. Bacci, C. Cucci, E. Del Federico, A. Ienco, A. Jerschow, J.M. Newman, M. Picollo, Vib. Spectrosc. 49 (2009) 80-83.

[43] M.L. Franquelo, A. Duran, L.K. Herrera, M.C. Jimenez de Haro, J.L. Perez-Rodriguez, J. Mol. Struct. 924-926 (2009) 404-412.

[44] R. Mazzeo, S. Prati, M. Quaranta, E. Joseph, E. Kendix, M. Galeotti, Anal. Bioanal. Chem. 392 (2008) 65-76.

[45] E. Knittle, W. Phillips, Q. Williams, Phys. Chem. Miner. 28 (2001) 630-640.

[46] A. Emandi, C.I. Vasiliu, P. Budrugeac, I. Stamatin, Cellul. Chem. Technol. 45 (2011) 579584.

[47] A.J. Hobro, J. Kuligowski, M. Döll, B. Lendl, Anal. Bioanal. Chem. 398 (2010) 2713-2722.

[48] S. Zumbühl, N.C. Scherrer, U. Eggenberger, Appl. Spectrosc. 68 (2014) 458-465.

[49] Z. Kaszowska, K. Malek, M. Pańczyk, A. Mikołajska, Vib. Spectrosc. 65 (2013) 1-11.

[50] M.R. Derrick, D. Stulik, J.M. Landry, Infrared Spectroscopy in Conservation Science, Getty Conservation Institute, 2000. 


\section{CAPTIONS FOR FIGURES}

Fig. 1. Spectra recorded on different fragment sections under $785 \mathrm{~nm}$ laser wavelength excitation with a portable HE785 spectrometer.

Fig. 2. Optical microscope images of the section of some fragments recovered from the right wood panel: white and red sample (top), dark blue and brown sample (centre); detail of the brown sample section where a green mineral compound seems present (bottom).

Fig. 3. Raman spectra of white spots from Christ flesh tone, recorded with a-b) $633 \mathrm{~nm}$, c) $785 \mathrm{~nm}$ and d) $1064 \mathrm{~nm}$ fixed Raman spectrometers. Spectra are vertically 'offset' for clarity.

Fig. 4. Raman spectra of red spots from Christ flesh tone, recorded with a) $532 \mathrm{~nm}$, b) $785 \mathrm{~nm}, \mathrm{c}$ ) $1064 \mathrm{~nm}$ and d) $633 \mathrm{~nm}$ fixed Raman spectrometers. Spectra are vertically 'offset' for clarity.

Fig. 5. Raman spectra of dark blue spots from the sky and Virgin veil, recorded with a) $532 \mathrm{~nm}$, b) $785 \mathrm{~nm}, \mathrm{~b}$ ') detail of the baseline subtracted b spectrum, c) $633 \mathrm{~nm}$ and d) $1064 \mathrm{~nm}$ fixed Raman spectrometers. Spectra are vertically 'offset' for clarity. See Supplementary Materials, Fig S2 for spectrum b) detail.

Fig. 6. a-d) ATR-FTIR spectra obtained with IR source and x36IR OLYMPUS objective.

Fig. 7. Representative XRF spectra collected in two places of a brown sample. 

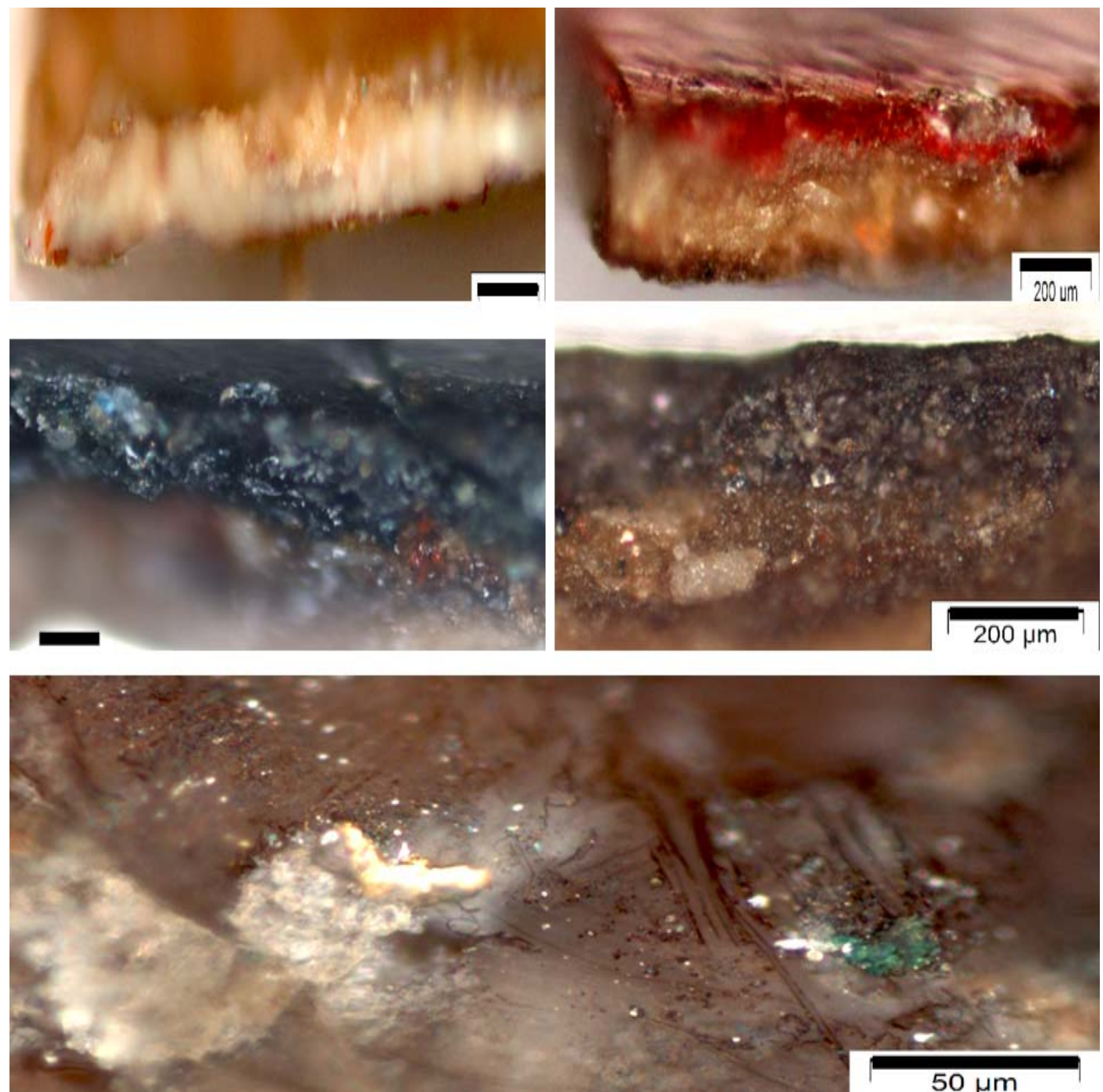

Fig 1 


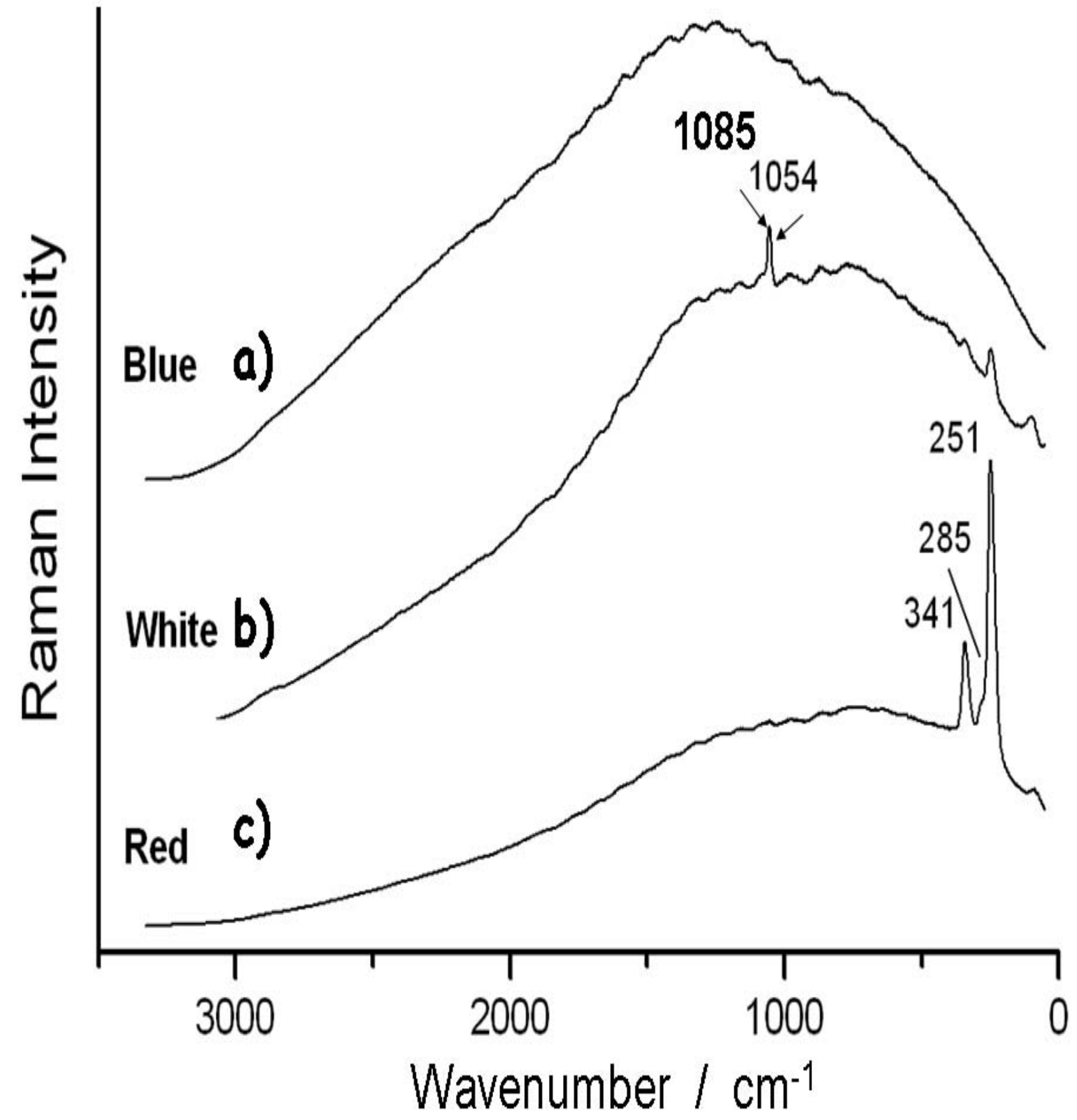

Fig 2 


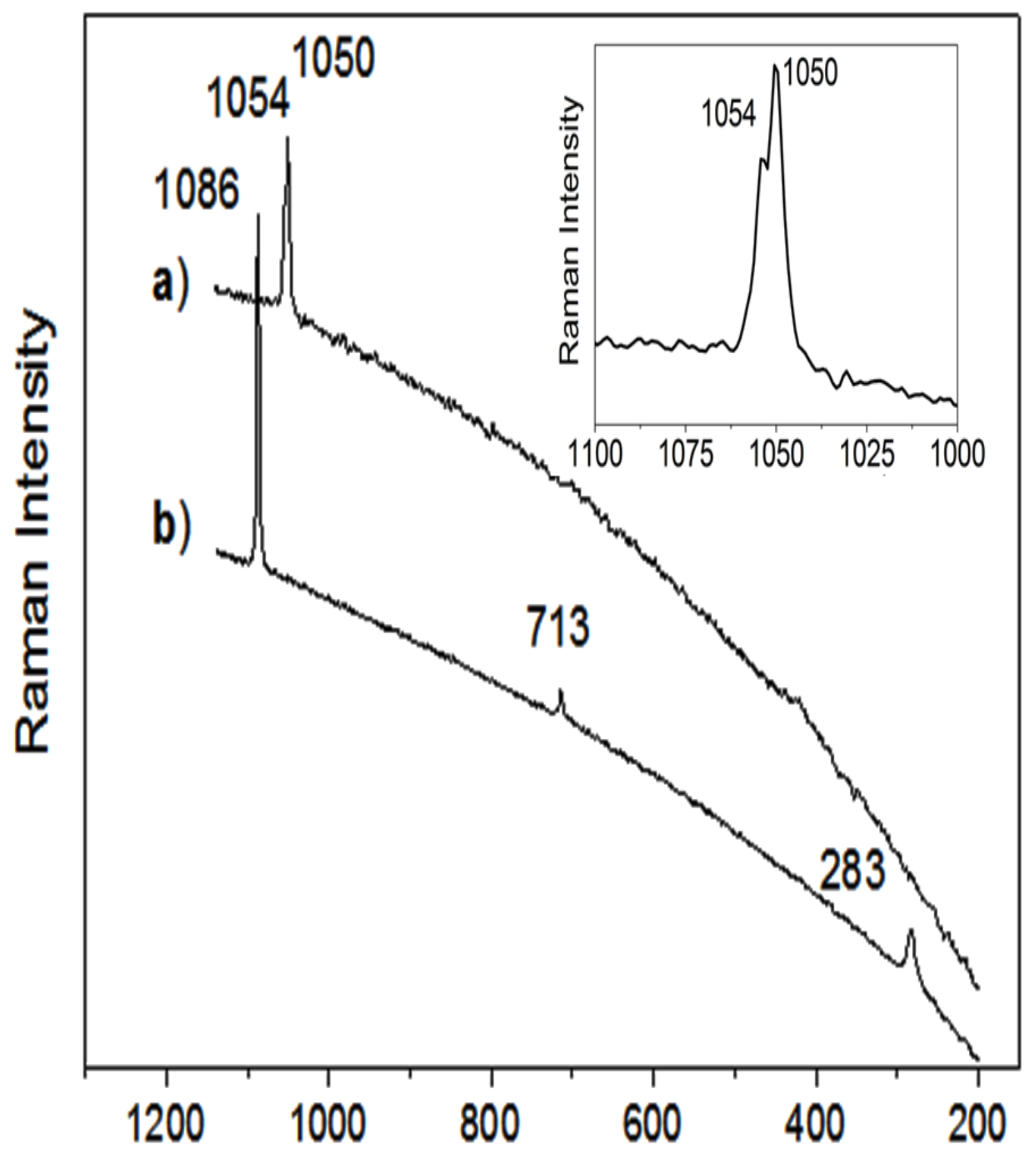




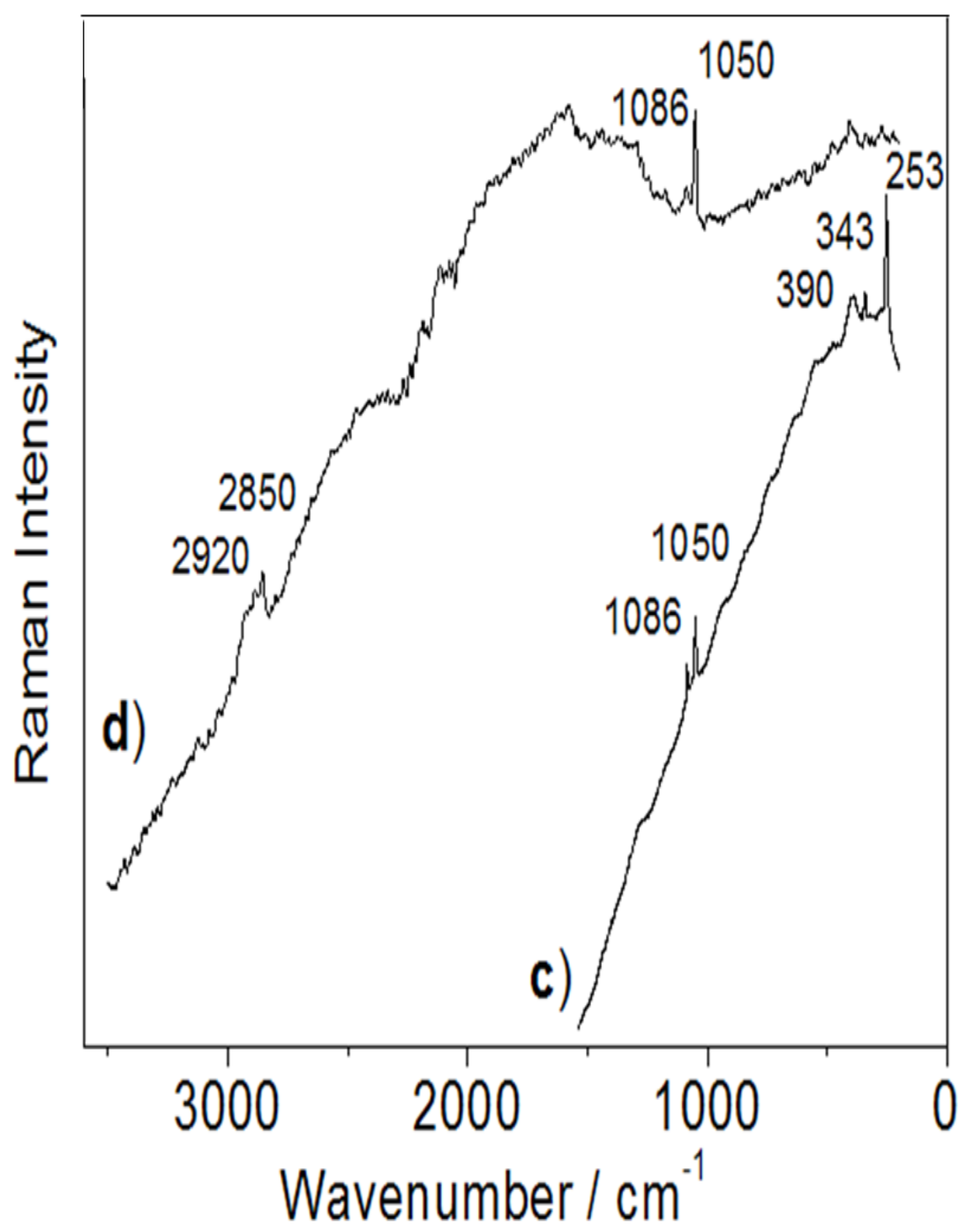

Fig 3 


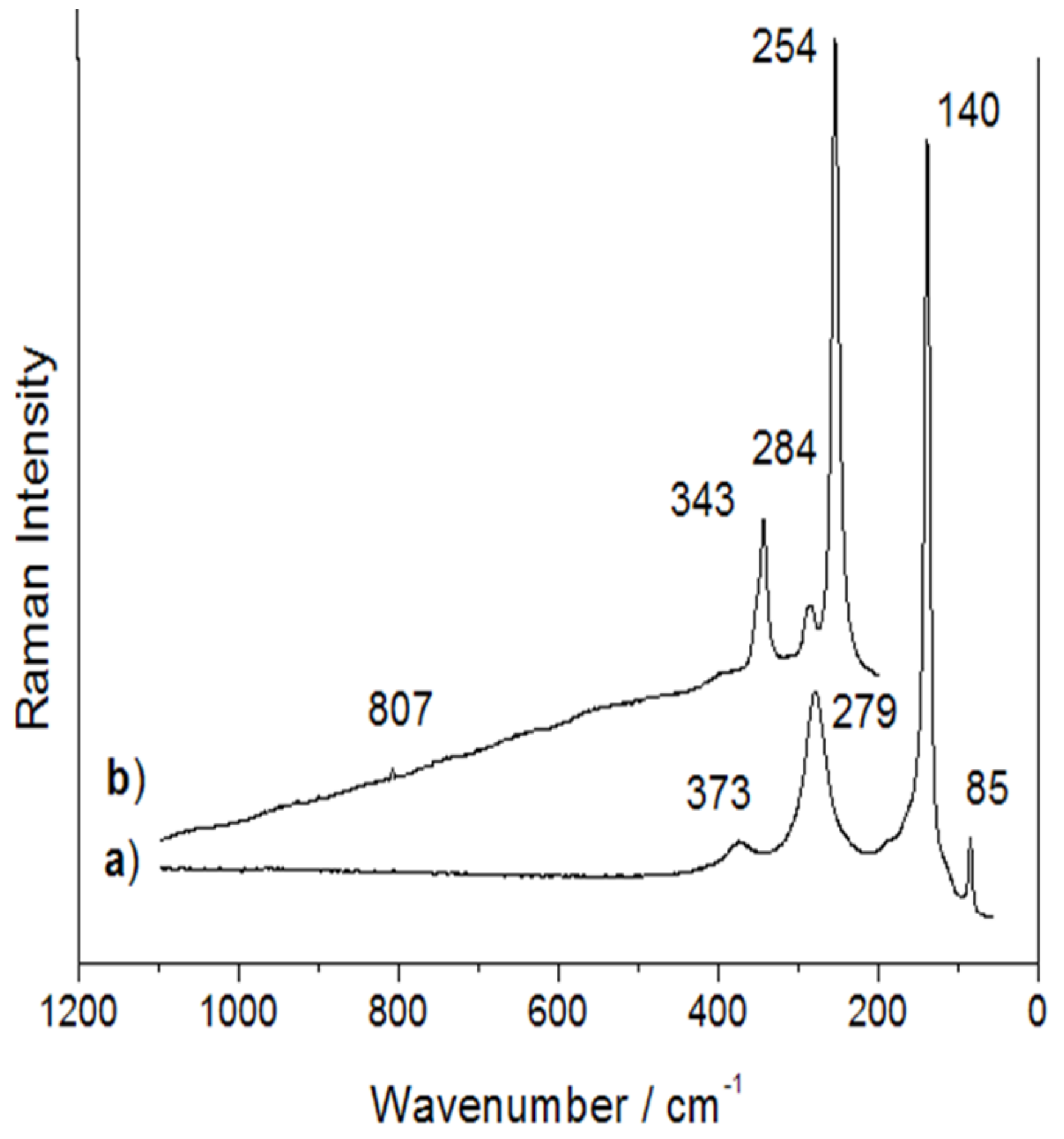




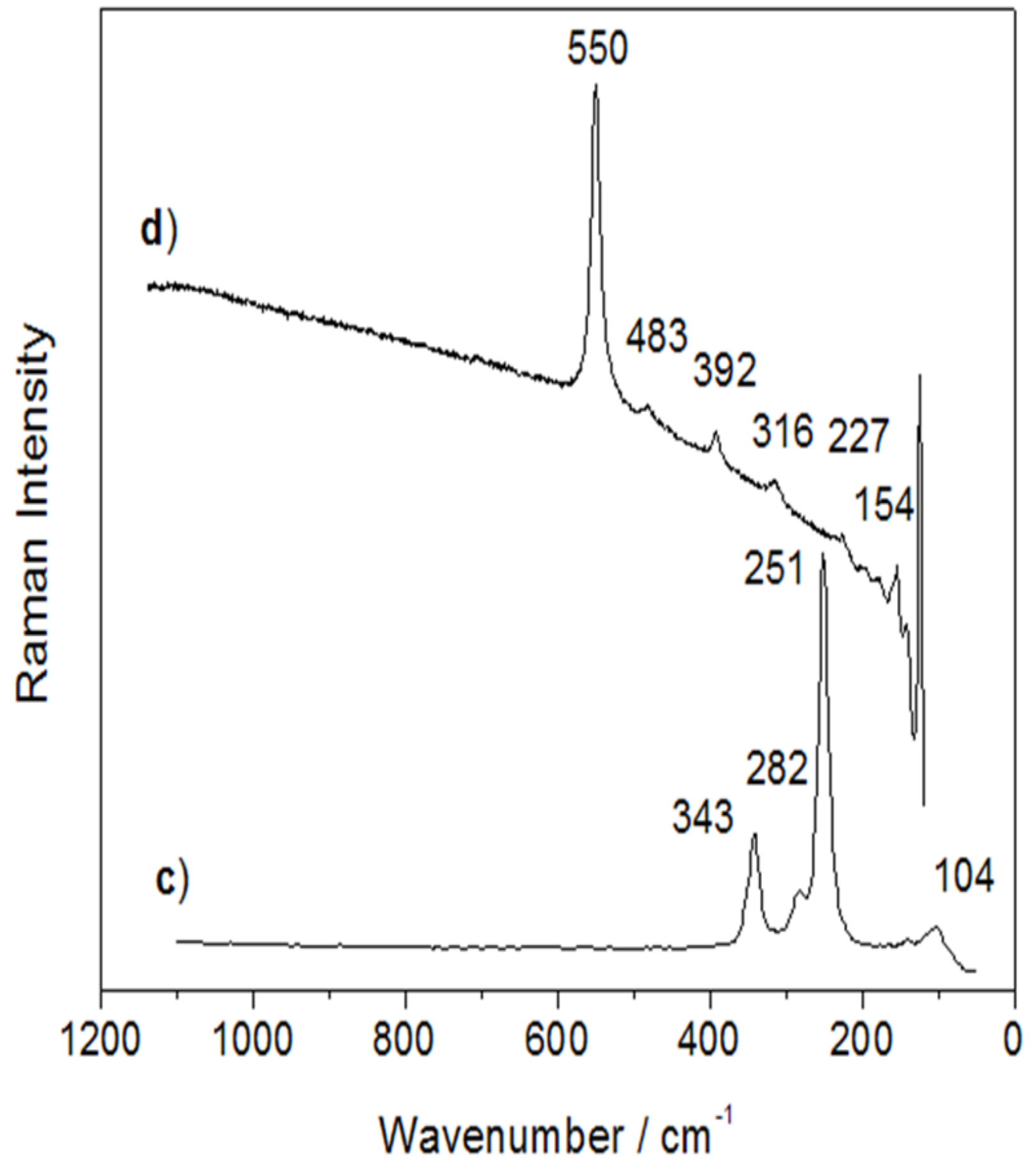

Fig 4 


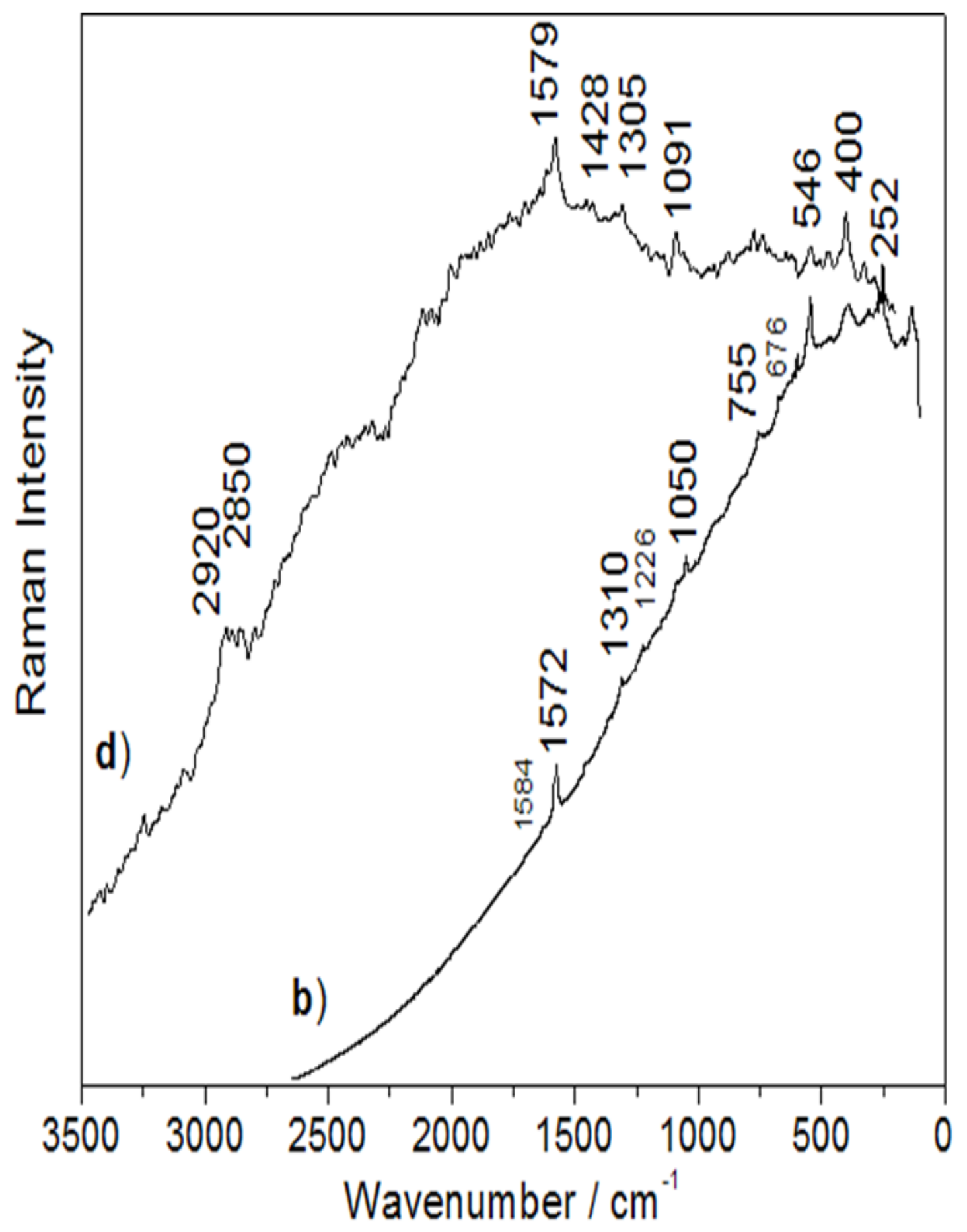




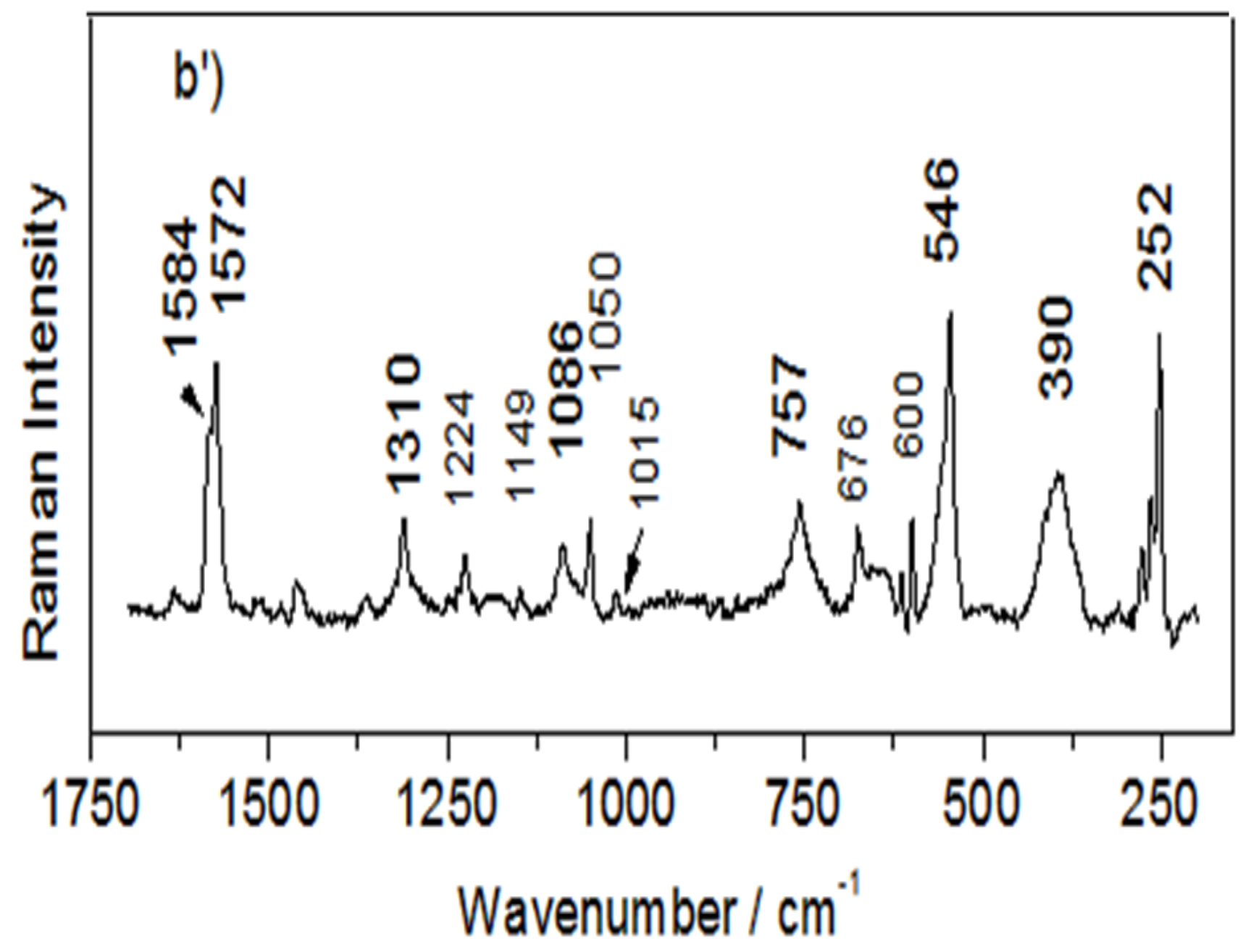




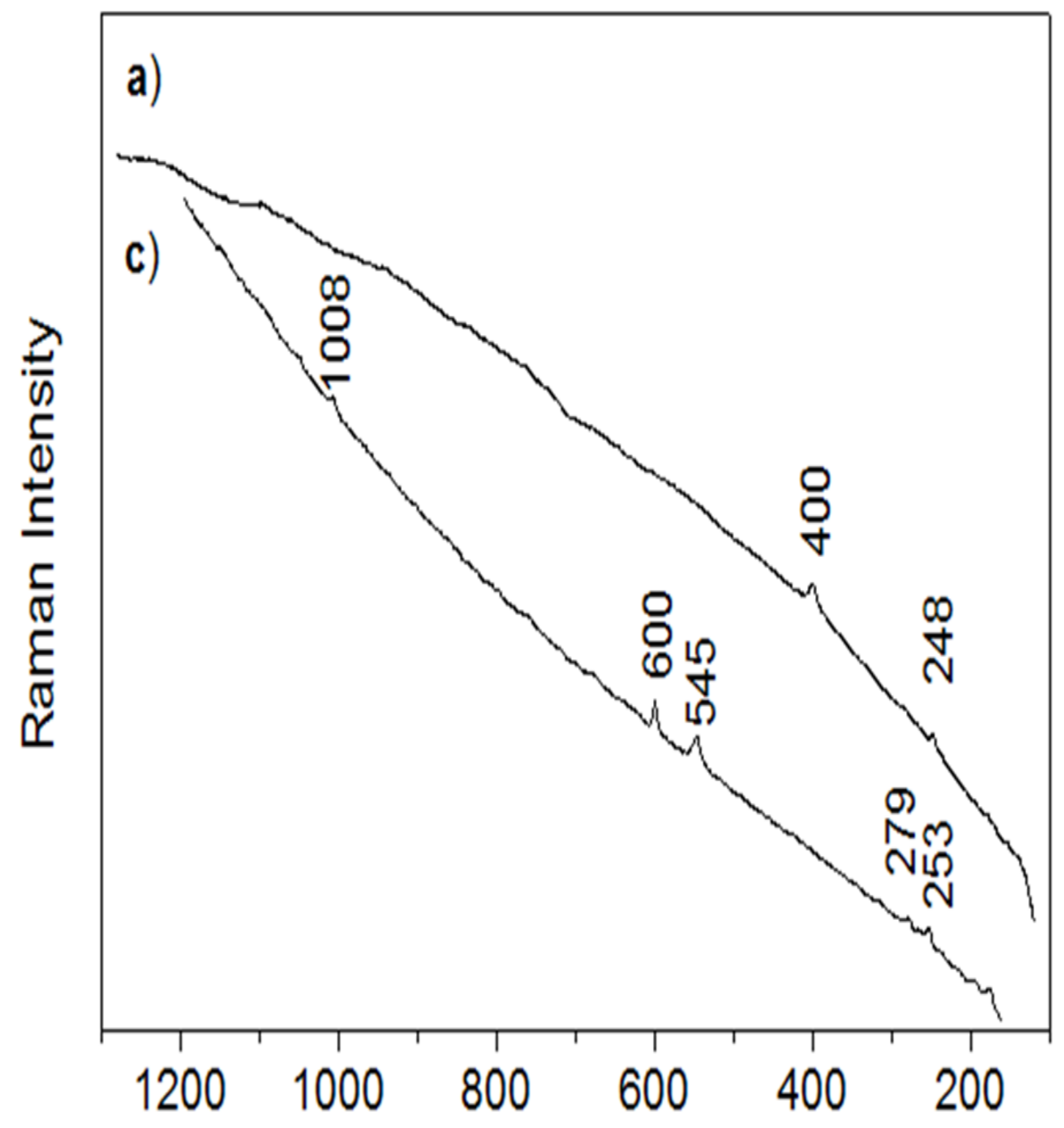

Fig 5 

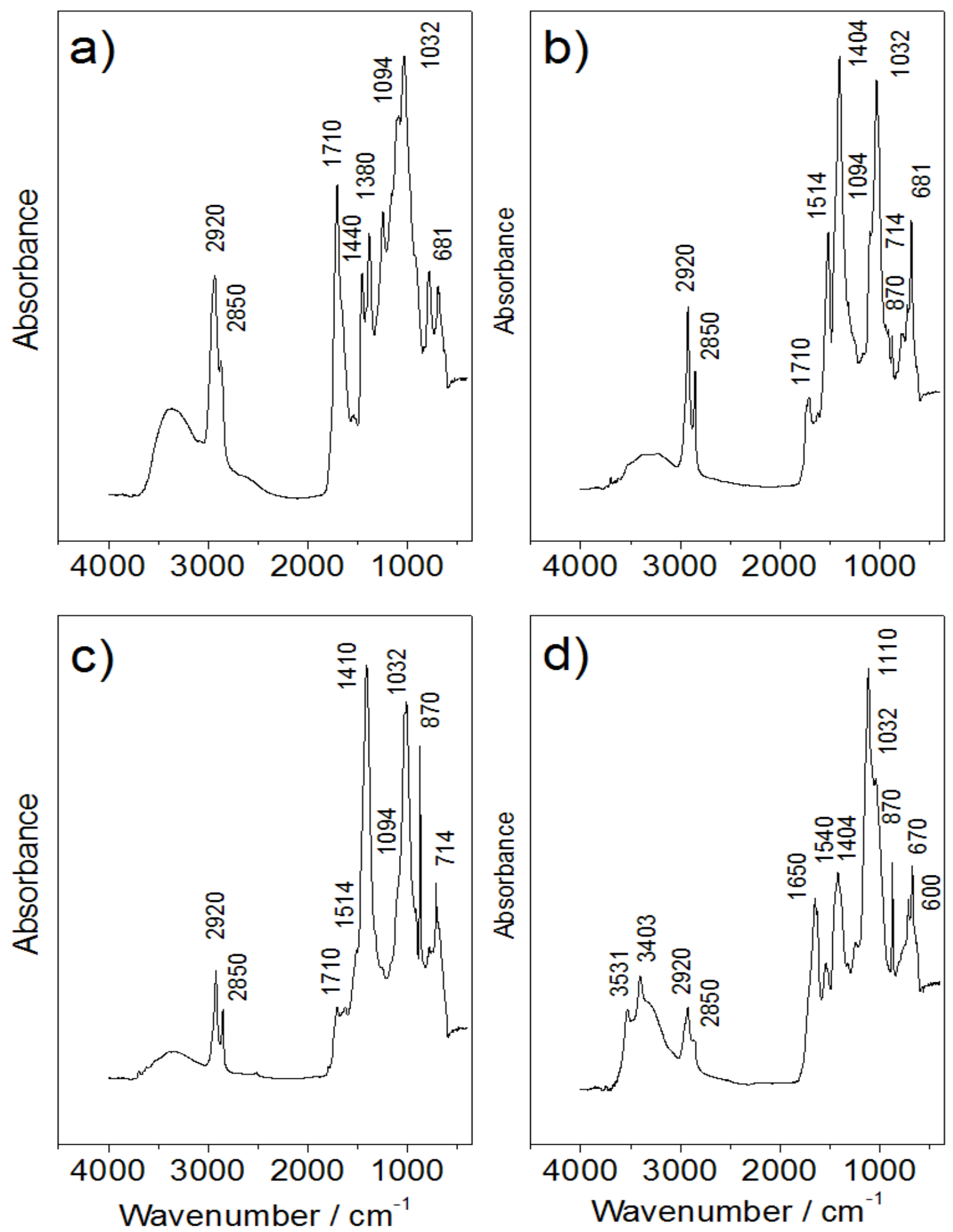

Fig 6 


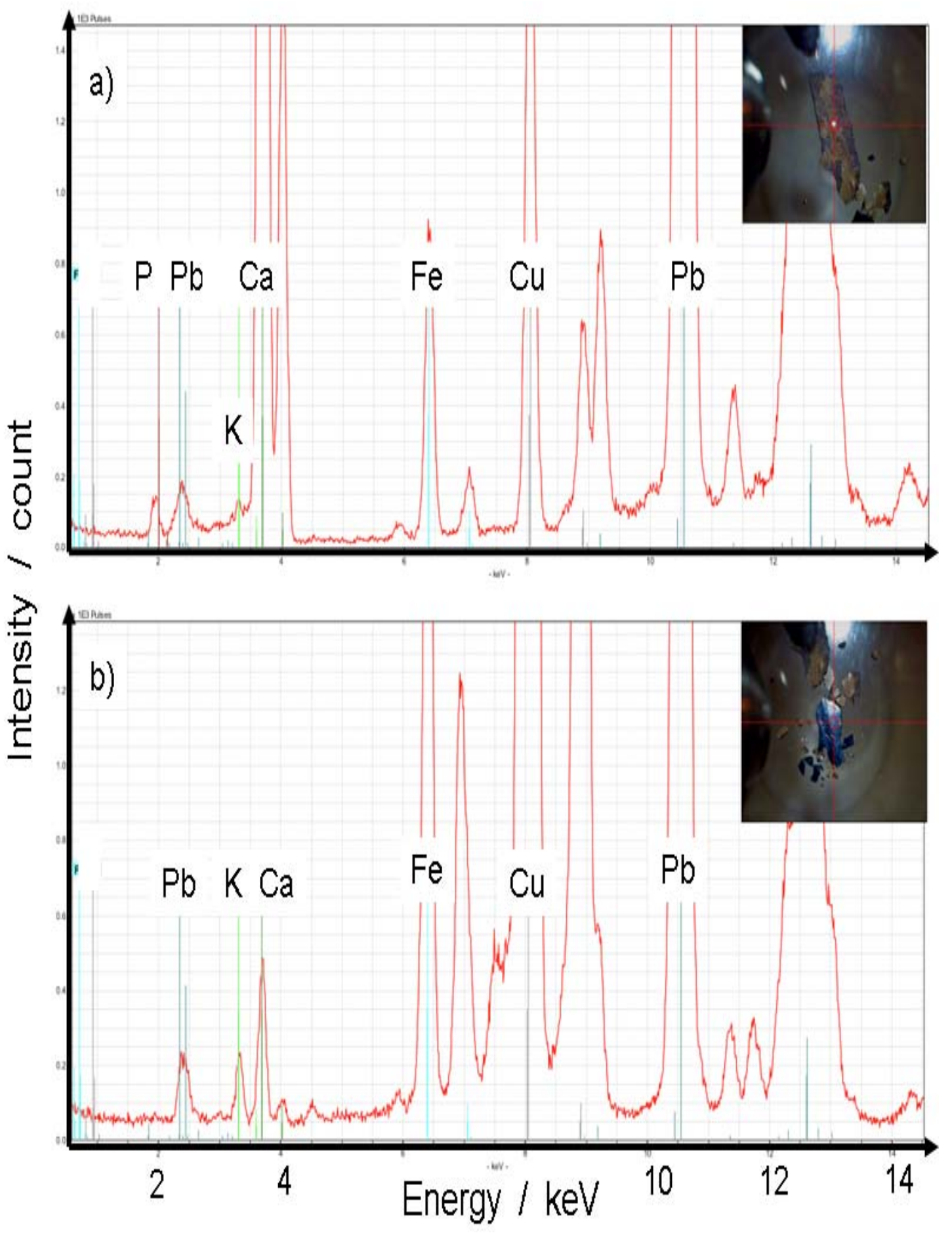

Fig 7 
Table 1. Pigments identified by Raman spectroscopy (laboratory instrumentation).

A cross indicates the efficiency of the laser line.

\begin{tabular}{|c|c|c|c|c|c|c|c|}
\hline Colour & Pigment & $\begin{array}{c}\text { Chemical } \\
\text { composition }\end{array}$ & $\begin{array}{c}532^{\mathrm{a}} \\
\mathrm{nm}\end{array}$ & $\begin{array}{c}633^{\mathrm{a}} \\
\mathrm{nm}\end{array}$ & $\begin{array}{c}785^{\mathrm{a}} \\
\mathrm{nm}\end{array}$ & $\begin{array}{c}1064 \\
\mathrm{~nm}\end{array}$ & $\begin{array}{c}\text { Raman bands }{ }^{\mathrm{b}} \\
\left(\mathrm{cm}^{-1}\right)\end{array}$ \\
\hline \multirow[t]{3}{*}{ White } & White lead & $2 \mathrm{PbCO}_{3} \mathrm{~Pb}(\mathrm{OH})_{2}$ & & $\mathrm{x}$ & $\mathrm{x}$ & $\mathrm{x}$ & $1050 \mathrm{vs}, 1054 \mathrm{~s}$ \\
\hline & Calcite & $\mathrm{CaCO}_{3}$ & & $\mathrm{x}$ & $\mathrm{x}$ & $\mathrm{x}$ & $283 \mathrm{~m}, 714 \mathrm{~m}, 1086 \mathrm{vs}$ \\
\hline & Gypsum & $\mathrm{CaSO}_{4} 2 \mathrm{H}_{2} \mathrm{O}$ & & $\mathrm{x}$ & & & $1007 \mathrm{w}$ \\
\hline \multirow[t]{3}{*}{ Red } & Litharge & $\mathrm{PbO}$ & $\mathrm{x}$ & & $\mathrm{x}$ & & $86 \mathrm{~m}, 139 \mathrm{vs}, 279 \mathrm{~m}, 347 \mathrm{~m}$ \\
\hline & Vermilion & $\mathrm{HgS}$ & & $\mathrm{x}$ & $\mathrm{x}$ & $\mathrm{x}$ & $254 \mathrm{vs}, 284 \mathrm{w}, 343 \mathrm{~m}$ \\
\hline & Minium & $\mathrm{Pb}_{3} \mathrm{O}_{4}$ & $\mathrm{x}$ & $\mathrm{x}$ & $\mathrm{x}$ & & $\begin{array}{l}122 \mathrm{vs}, 153 \mathrm{w}, 226 \mathrm{w}, 314 \mathrm{w}, 392 \mathrm{w}, 551 \\
\text { vs }\end{array}$ \\
\hline \multirow[t]{3}{*}{ Blue } & Azurite & $2 \mathrm{CuCO}_{3} \mathrm{Cu}(\mathrm{OH})_{2}$ & $\mathrm{x}$ & & $\mathrm{x}$ & $\mathrm{x}$ & $250 \mathrm{~m}, 400 \mathrm{vs}, 1091 \mathrm{~m}, 1404 \mathrm{vs}, 1459 \mathrm{w}$ \\
\hline & Indigo & $\mathrm{C}_{16} \mathrm{H}_{10} \mathrm{~N}_{2} \mathrm{O}_{2}$ & & $\mathrm{x}$ & $\mathrm{x}$ & $\mathrm{x}$ & $\begin{array}{l}254 \mathrm{~m}, 279 \mathrm{w}, 547 \mathrm{~m}, 600 \mathrm{~m}, 756 \mathrm{w}, 1225 \\
\mathrm{w}, 1311 \mathrm{w}, 1574 \mathrm{vs}, 1584 \mathrm{~s}\end{array}$ \\
\hline & Lapis Lazuli & $\mathrm{Na} 8-10 \mathrm{Al}_{6} \mathrm{Si}_{6} \mathrm{O}_{24} \mathrm{~S}_{2-4}$ & & & $\mathrm{x}$ & & 390 vs, 545 vs, 1032 w, 1707 vw \\
\hline \multirow[t]{4}{*}{ Brown } & Calcite & $\mathrm{CaCO}_{3}$ & & $\mathrm{x}$ & $\mathrm{x}$ & $\mathrm{x}$ & $713 \mathrm{~m}, 870 \mathrm{~s}, 1393 \mathrm{~s}$ \\
\hline & Gypsum & $\mathrm{CaSO}_{4} 2 \mathrm{H}_{2} \mathrm{O}$ & & $\mathrm{x}$ & $\mathrm{x}$ & $\mathrm{x}$ & $\begin{array}{l}600 \mathrm{~m}, 670 \mathrm{~m}, 1109 \mathrm{~m}, 1795 \mathrm{w}, 3403 \mathrm{w}, \\
3523 \mathrm{w}\end{array}$ \\
\hline & Vermilion & $\mathrm{HgS}$ & & $\mathrm{x}$ & $\mathrm{x}$ & $\mathrm{x}$ & $254 \mathrm{vs}, 284 \mathrm{w}, 343 \mathrm{~m}$ \\
\hline & Minium & $\mathrm{Pb}_{3} \mathrm{O}_{4}$ & & $\mathrm{x}$ & $\mathrm{x}$ & & $\begin{array}{l}122 \mathrm{vs}, 153 \mathrm{w}, 226 \mathrm{w}, 314 \mathrm{w}, 392 \mathrm{w}, 551 \\
\text { vs }\end{array}$ \\
\hline Identified & & & 3 & 10 & 12 & 8 & \\
\hline
\end{tabular}

${ }^{\mathrm{a}}$ Transportable instrument.

White and red samples taken by the Christ flesh tone; light blue and dark blue samples taken by the sky and the Virgin veil, respectively; brown sample taken by the Christ cloth.

${ }^{\mathrm{b}} \mathrm{s}$ : strong, m: medium, w: weak, v: very.

Table 2. Compounds identified by infrared spectroscopy.

\begin{tabular}{|l|l|}
\hline Compound & Infrared bands $\mathbf{( c m}^{-\mathbf{1}} \mathbf{)}$ \\
\hline & \\
\hline White lead & $681,1380-1440,1710-1730,3534$ \\
\hline Gypsum & $600,670,1110,1795,3403,3531$ \\
\hline Calcite & $714,870,1410$ \\
\hline Cerussite & $681,838,1051,1398$ \\
\hline Minium & 1514 \\
\hline Lapis Lazuli & 1032,1097 \\
\hline Indigo & 1076 \\
\hline Azurite & 1404 \\
\hline Wood & $\begin{array}{l}897,1032,1153,1231,1322,1375,1420,1458,1507,1648,1707,1728, \\
2854,2924\end{array}$ \\
\hline
\end{tabular}




\begin{tabular}{|l|l|}
\hline Egg & $1434,1470,1546,1650,1730,2850,2920$ \\
\hline Glue & 1654,1707 \\
\hline Terpenic resin & $1379,1453,1696-1698$ \\
\hline $\begin{array}{l}\text { Calcium } \\
\text { oxalates }\end{array}$ & 1320 \\
\hline
\end{tabular}

